МРНТИ 0603

\title{
Тулейбаева А.
}

докторант PHD, Казахский национальный университет имени аль-Фараби, Казахстан, Алматы, e-mail: tuleibayeva888@gmail.com

\section{ЭВОАЮЦИЯ РЫНКА ТРУАА И МЕЖАУНАРОАНАЯ ТРУАОВАЯ МИГРАЦИЯ: ТЕОРЕТИЧЕСКИЙ АСПЕКТ ИССАЕАОВАНИЙ}

\begin{abstract}
Процесс экономической глобализации, охватив практически все сферы человеческой деятельности, значительно расширил в XXI веке мировые экономические связи, что, в свою очередь, привело к формированию более сложной структуры международного рынка труда, изменению системы регулирования рынка рабочей силы, появлению новых тенденций в межАународной трудовой миграции.

Целью статьи является рассмотрение теоретических аспектов в исследованиях рынка труда во взаимосвязи с международной трудовой миграцией. В научных трудах западных авторов обращается внимание на эволюцию такого процесса, вслеАствие которого национальные рынки труда большинства ведущих стран уже не являются изолированными структурами, они Аавно интегрированы, и более того, они связаны с динамикой перемещения трудовой силы. Транснациональная миграция трудовых ресурсов сегодня приобрела регулярный, устойчивый характер.

Изучение места назначения мигрантов, определение особенностей трудовой миграции указывает на недостаточность теоретического осмысления изучаемых процессов в региональном срезе. Теоретическая значимость работы заключается в углублении и развитии методологии исследования мирового и национального рынков труда в условиях глобализации и технологической трансформации, что, в свою очередь, способствует согласованию разных научных подходов и преодолению фрагментарности научного знания в данной важной научной области. В практическом плане изучение данной темы позволит использовать основные выводы в Аальнейшем научном исследовании и анализе процесса современного развития мирового и национального рынка труда, выявить ключевые направления в развитии международной трудовой миграции.
\end{abstract}

Ключевые слова: труд, миграция, эволюция, международная, история.

Tuleubaeva A.S.

PhD student, Al-Farabi Kazakh National University, Kazakhstan, Almaty, e-mail: tuleibayeva888@gmail.com

\section{Evolution of the labor market and international labor migration: the theoretical aspect of research}

The process of economic globalization, covering virtually all spheres of human activity, significantly expanded the world economic ties in the 21 st century, which in turn led to the formation of a more complex structure of the international labor market, a change in the regulation of the labor market, and the emergence of new trends in international labor migration.

The purpose of the article is to examine theoretical aspects in labor market research in conjunction with international labor migration. In the scientific works of Western authors, the evolution of such a process is studied, as a result of which the national labor markets of most leading countries are no longer isolated structures, they have long been integrated, and moreover, they are associated with the dynamics of the movement of labor force. Transnational migration of labor resources has now acquired a regular, sustainable character. 
The study of the destination of migrants, the definition of the peculiarities of labor migration indicates a lack of theoretical comprehension of the studied processes in the regional section. The theoretical significance of the work lies in the deepening and development of the methodology for studying the world and national labor markets in the context of globalization and technological transformation, which in turn facilitates the harmonization of different scientific approaches and overcoming the fragmented nature of scientific knowledge in this important scientific field. In practical terms, the study of this topic will allow us to use the main findings in further scientific research and analysis of the current development of the world and national labor market, to identify key areas in the development of international labor migration.

Key words: labor, migration, evolution, international, history.

Тулейбаева А.С.

PHD докторант, әл-Фараби атындағы Қазақ, ұлттық университеті,

Қазақстан, Амматы, e-mail: tuleibayeva888@gmail.com

\title{
Еңбек нарығының эволюциясы және халықаралық еңбек көші-қоны: зерттеудің теориямық аспектісі
}

\begin{abstract}
Экономикалық жаһандану үлерісі адам әрекетінің барлық саласын қамти отырып, XXI ғасырда әлемдік экономикалық байланыстарды айтарлықтай кеңейтті, өз кезегінде, халықаралық еңбек құрылымының күрделі құрылымына, жұмыс күшінің нарығын реттеу жүйесінің өзгерісіне, халықаралық, еңбек көші-қонының жаңа тенденцияларының туындауына алып келді.

Мақала мақсаты халықаралық еңбек көші-қонымен өзара байланыса еңбек нарығын зерттеулерде теориялық аспектілерін қарау болып табылады. Батыс авторлардың ғылыми еңбектерінде осындай үрдістің эволюциясына назар аударылады, оның са^дары көптеген жетекші елдердің ұлттық нарықтарының салдары оқшауланған құрылымдары болып табылады, олар бұрыннан кіріктірілген, оның үстіне, олар еңбек күшін ауыстыру динамикасымен байланысты. Еңбек ресурстарының трансұлттық көші-қоны бүгінде жүйелі, тұрақты сипатты.

Мигранттарды тағайындау орнын зерттеу, еңбек көшіп-қонының ерекшеліктерін анықтау, аймақтық бөлімде зерттелетін үрдістердің теориялық түсінуінің жеткіліксіздігіне көрсетіледі. Жұмыстың теориялық маңыздылығы әлемдік және ұлттық еңбек нарығының әдіснамасын, жаһандану жағдайларында және технологиялық трансформацияда тереңдету және дамытуда болып отыр. Бұл өз кезегінде, әр түрлі ғылыми тәсілдерін келісуге және осы маңызды ғылыми салада ғылыми білімнің фрагменттерін игеруге қабілеттендіреді.

Практикалық жоспарда осы тақырыпты зерттеу келесі ғылыми зерттеуде негізгі қорытындыларын қолдануға және әлемдік және ұлттық еңбек нарығын дамыту қазіргі заманғы ғылыми зерттеулерде дамытуға, үдеріс талдауына мүмкіндік береді, халықаралық еңбек көшіқонын дамытуда негізгі бағыттарын анықтайды.
\end{abstract}

Түйін сөздер: еңбек, көші-қон, эволюция, халықаралық, тарих.

\section{Введение}

Исследование международного рынка труда обусловлено рядом новых тенденций в мировой экономике, связанных с процессами глобализации, экономическими вызовами, перманентными кризисами и иными обстоятельствами. Состояние рынков труда практически ведущих стран мира, включая постсоветские государства, в значительной степени определяется темпами экономического и социального роста, зависит от технической и организационной модернизации, прогресса в области рыночных отношений, от способности своевременно реагировать на динамику мирового экономического развития.

Современный международный рынок труда включает также национальные экономики большого евразийского пространства, где весо- мое место занимает Казахстан. Международные рынки труда относятся к наиболее подвижной и динамичной системе, которая во многом определяется внешними факторами. Рынки труда втянуты как в международные экономические отношения, так в региональные процессы экономической интеграции. Если для мировой экономической системы особую актуальность приобретает проблема эффективного функционирования рынка труда, то для Казахстана добавилась проблема модернизации экономической системы в целом.

С недавнего времени остро встал вопрос о создании новой формы «интеллектуальной экономики». Несмотря на то, что Казахстан по итогам 2016 г. занял 20 место в Глобальном индексе конкурентоспособности Всемирного экономического форума и вошёл в тридцатку стран- 
лидеров по фактору «эффективность рынка труда» (Казахстан вошел в тридцатку мировых лидеров...), остается ещё ряд взаимосвязанных и сложных проблем, требующих своего решения.

Эволюционные изменения рынка труда обусловлены коренной трансформацией Казахстана и стран евразийского региона в результате перехода к рыночной экономике. Сегодня эти изменения связаны с потребностями мирового рынка труда, не остающегося в стороне от технологического прогресса, но который значительно обостряет социальные противоречия в области трудовых отношений. Автоматизация производства сокращает количество рабочих мест, растет безработица, увеличиваются потоки трудовой миграции. Совершенно очевидно, что время потребовало теоретического переосмысления и изучения экономических моделей с особенностями рынка труда, разных категорий занятости, безработицы, международной миграции и т.д.

Международный рынок труда, ставший неотъемлемой частью глобальной экономики, формируется в основном путём миграции капитала и рабочей силы, и также путём постепенной интернационализации и интеграции/слияния национальных рынков труда. В результате стираются различного рода границы, происходит устранение правовых, межкультурных, этнических и иных препятствий. Рынки труда все интенсивнее втягивают в свою область демографические, трудовые, социальные, политические отношения. В связи с этим особую актуальность приобретает исследование эволюционных изменений рынка труда, закономерностей его формирования и функционирования в переходной экономике так называемых новых стран. Важным компонентом системы международного рынка труда стали увеличивающиеся потоки трудовой миграции в международном масштабе. Изучение места назначения мигрантов, определение особенностей трудовой миграции указывает на недостаточность исследований в региональном срезе. Исследование эволюции международного рынка труда и связанным с ним формированием международной трудовой миграцией является общей целью данной статьи.

Отдельные вопросы изучаемой темы рассматривались в научных трудах казахстанских и зарубежных авторов. Обращается внимание на определяющую тенденцию в эволюции национальных рынков труда большинства ведущих стран, которые уже не являются изолированными структурами и давно развиваются в интегрированной международной среде, связа- ны с динамикой перемещения трудовой силы. Транснациональная миграция трудовых ресурсов сегодня приобрела регулярный, устойчивый характер. Сравнительно новой тенденцией в развитии мирового хозяйства, наметившейся в процессе интернационализации капитала и рынка труда, называют создание единого социального пространства и глобализацию социальной политики. Неурегулированные правовые вопросы нередко приводят к серьезным межгосударственным спорам и противоречиям в сфере рабочей силы, трудовой миграции, и в целом, рынка труда. Потребность в практических заключениях и теоретическом обосновании вопроса о создании рынка труда обуславливает актуальность данного исследования, результаты которого могут способствовать формированию научно обоснованной социальной политики в Казахстане, направленной на снижение рисков нерегулируемой миграции, снижению негативного влияния на рынки труда в условиях глобальных вызовов.

$K$ теоретической и методологической базе изучения темы относятся общенаучные методы и подходы к исследованию формирующегося рынка труда и решению социально-экономических проблем; историко-логический и системный подходы; фундаментальные концепции управления экономики, научных гипотез, которые нашли свое отображение в работах классиков экономической науки, современных ученых, исследователей СНГ и зарубежных стран. Тема создания и функционирования рынка труда как научная проблема впервые была затронута в теоретических трудах классиков политической экономии - А. Смита (Смит, 1993:570), Ст. Милля (Милль, 2007:1040) К. Маркса (Маркс, 1989:508), а также и других представителей различных экономических школ, продолжающих в совокупности опираться на классические идеи и теорию рынка труда, теорию трудовой миграции.

Несмотря на критическое восприятие политического наследия К. Маркса, его экономическая теория выдержала испытание временем. В этом смысле теория К. Маркса, считавшего, что рабочая сила как «совокупность физических и духовных способностей, которыми обладает организм, живая личность человека» является товаром, а производственные отношения базируются на свободной купле-продаже рабочей силы, где ее ценой является заработная плата», приемлема для обозначения дискуссии о роли рынка труда и анализа современных проблем, связанных с трудовыми ресурсами. Концептуальные положения 
рынка, разработанные и введенные Марксом понятия в науку используются исследователями и сегодня. Так, понятия «рынок труда», «рабочая сила», введенные им в научный оборот, стали актуальными категориями. В нашем случае теория прибавочной стоимости Маркса и теория относительного перенаселения обосновывают неизбежность формирования резервной армии труда (безработицы), которая приводит к движению (миграции) трудовой силы в международном масштабе.

Развивая идеи классиков политической экономии, английский экономист А. Маршалл (Маршал, 2007: 832) и его последователи сформулировали неоклассическую модель рынка труда. Для решения задач данного исследования и доказательства гипотезы о несовершенстве современного рынка труда и о существующей неопределенности на рынке труда приемлемы концептуальные положения Маршалла, прежде всего, о возрастающем значении инвестиций в человеческий капитал. Утверждается, что именно человек (индивид) является реальным двигателем экономического роста. Важна концепция производного спроса и зависимость возможностей профсоюзов от эластичности спроса на труд, классификация трудовых ресурсов. Таким образом, с методологической точки зрения оправданно рассмотрение различных, порой конкурирующих концепций рынка труда, прежде всего для того, чтобы остановиться на более приемлемом варианте.

Учение Адама Смита о рынке труда продолжил яркий представитель неоавстрийской либеральной школы Фридрих фон Хайек (Хайек, 2003: 149), утверждавший, что рынок представляет собой естественный процесс, порожденный действиями индивидуумов, пытающихся достичь своей цели. Важна его мысль, как из разнообразия действий индивидуумов формируется экономический порядок, а рынок, который не согласован с организационной точки зрения, сочетает различные конкурирующие цели. Рынок труда получил свое новое понимание, новое переосмысление.

В монетаристской модели рынка труда, предложенной М. Фридменом (Фридмен, 2003:149), политика государства направлена на достижение естественного уровня безработицы, отражающего структурные диспропорции на рынке труда и не связанного с циклической конъюнктурой в экономике. В целом, естественный уровень безработицы отражает структурные характеристики как товарных рынков, так и рынка труда.
Популярные в XX веке идеи английского экономиста Дж. Кейнса, изложенные в его главном труде «Общая теория занятости процента и денег», казалось, положили конец теории «невидимой руки» рынка. Напомним, знаменитая метафора о «невидимой руке», заимствованная из произведения о пчёлах Бернарда Мандевилля не менее знаменитым классиком Адамом Смитом в его труде «Богатство народов», стала смысловым выражением и направлением экономической философии. В различных теориях рынка присутствовала «невидимая рука», в некоторых трудах по экономике невидимая рука вновь возрождается. Рынок труда в периоды экономических кризисов будет понят благодаря кейнсианской теории о необходимости государственного вмешательства в регулирование экономики с целью достижения полной занятости (Кейнс, 1993: 287). Утверждение Дж. Кейнса о том, что в рыночном хозяйстве не существует механизма, гарантирующего полную занятость, а причиной безработицы является отсутствие синхронности в принятии основных экономических решений о сбережениях и инвестициях, приемлемо для апробации гипотезы о прямой связи формирования рынка труда и трудовой миграции.

Кейнсианское направление в экономической науке и макроэкономическая теория продолжают развиваться и во многом определяют экономическую политику многих стран. Практический вклад теории Кейнса в экономику США и Западной Европы оценивается сегодня с точки зрения экономического роста ведущих западных стран и перспектив подобного роста в не западных странах. Так, теория Дж. М. Кейнса, порывая с классическими теориями капитализма как саморегулирующейся системы, утверждала положение о пределах возможностей мировой экономики в использовании производительных и трудовых ресурсов, о сотрясении мировых рынков периодическими кризисами, о возрастании потоков миграции.

Обращаясь к вопросу о трудовой миграции, отметим, что современные концептуальные идеи происходят из теории народонаселения $\mathrm{T}$. Мальтуса. Английский ученый заложил основы изучения миграции населения в своем труде «Опыт о законе народонаселения» ещё в 1798 году (Мальтус, 1993: 124). Опираясь на теорию народонаселения, мы выявляем зависимую связь экономического благосостояния народа от социально-демографических проблем. Миграция же определяется как «инструмент», регулирующий народонаселение, и как политика «выселения 
чрезмерно густого населения» в незаселенные местности. Ряд современных западных экономистов придерживаются теории Мальтуса, утверждают тезис о том, что избыток народонаселения в отдельных странах активно и давно подвигает народы к миграции.

Американские неомальтузианцы Р. Осборн и Т. Уентоу в книге «Обновлённое управление» увязывают между собой несоответствия экономического роста отдельных высокоразвитых стран со значительным ростом народонаселения и запасов жизненных ресурсов земли (Osborne "Renovating Government") (Лопатникова, 2001: 533).

В основе большинства существующих современных теорий происхождения (возникновения миграции) лежат индивидуальный и структурный подходы, выделяются неоклассическая, новая экономика миграции, двойной рынок труда, мировые системы и теории постоянной миграции: социальная сеть, институциональная, миграционная система. По сути, сложность процессов трудовой миграции населения, ее причин, мотивов и последствий объясняет появление множества теорий миграции, которые стали исходной платформой для всестороннего изучения феномена трудовой миграции.

МОТ и нормативно-правовое регулирование

Проблематика международного рынка труда и трудовой миграции исследуется на основе основополагающих международных конвенций и правил, принятых ООН и Международной организацией труда (МОТ). МОТ, созданная в 1919 г., с 1946 г. является единственным специализированным и наиболее авторитетным институтом $\mathrm{OOH}$ по вопросам регулирования трудовых отношений.

МОТ разрабатьвает международные трудовые нормы в форме конвенций и рекомендациий, устанавливая минимальные стандартьл в области основополагающих трудовых прав. В их числе Конвенция № 97 «О трудящихся-мигран$\max$ (пересмотренная в 1949 году)» (МОТ, Женева, 2007), одноименная Рекомендащия № 86, Конвенциия № 143 «О злоупотреблениях в области миграции и об обеспечении трудящимся-мигрантам равенства возможностей $и$ обращения» (1975), «Европейская Конвенция о правовом статусе трудящихся-мигрантов, 24 ноября 1977» (Конвенц̧ия № 143). Если сравнить акть ООН и МОТ, то это аналогичные документы с точки зрения общих иелей, которые заключаются в том, чтобь содействовать осуществлению прав и защчите лиц мигрирующих в цеелях полу- чения работы; сдерживать и ликвидировать нелегальную миграцию. Вместе с тем, имеются некоторые отличия в толковании терминов, прежде всего термина «трудящийся мигрант». Конвенция ООН - более широкая, нежели МOT, она охватывает трудящихся приграничных районов, моряков и лиц с самостоятельной занятостью; сюда также включены определения «члены семей трудящихся-мигрантов» (Резолюция 45/158 Генеральной Ассамблеи от 18 декабря 1990 года).

Посредством различных структур МOT продвигаются принциипь сочиальной справедливости, права человека и права в сфере труда, признанные в международном праве. В системе ООН МОТ обладает уникальной трехсторонней структурой, в которой объединения работодателей и трудящихся имеют равный голос с правительствами в работе руководящих органов MOT (Губайдуллина, 2004: 104-111). В своем комментарии к докладу Генеральный директор МОТ Гай Райдер (Guy Ryder) заявил: «Эти аналитические данные - значительный вклад MOT в поддержку государств-членов для выполнения Программы устойчивого развития до 2030 года, особенно в части достижения Цели 8 , касающейся защиты всех работников, включая работников-мигрантов, и Цели 10 - реализация эффективно управляемой миграционной политики. Теперь у тех, кто принимает решения, будут реальные данные, на которых можно строить политику» (Доклад Глобальные оценки MOT, 2015).

Приведем некоторые данные из исследования Международной организации труда. Работники-мигранты в мире сегодня составляют 150,3 млн из приблизительно 232 млн международных мигрантов. Работники-мигранты составляют 72,7 \% от 206,6 млн мигрантов трудоспособного возраста (15 лет и старше). Большинство из них - 83,7 млн - мужчины, 66,6 млн - женщины. Трудовая миграция - явление, затрагивающее все регионы мира, однако почти половина (48,5 процента) работников-мигрантов сосредоточена в двух крупных регионах - Северной Америке и Северной, Южной и Западной Европе. В арабских государствах работники-мигранты составляют наибольшую долю всех работников $-35,6 \%$.

Особое внимание в докладе к домашним работникам-мигрантам уделяется значительному числу домашних работников-мигрантов в мире и заметному гендерному различию в этом секторе. Домашний труд - один из наименее под- 
дающихся регулированию секторов экономики, и поэтому вызывает особую озабоченность МОТ. Из-за большого количества занятых в нем женщин-мигрантов и относительно плохой «видимости» рабочей силы в этом секторе отмечаются многочисленные случаи дискриминации в самых разных формах. Из 67,1 млн домашних работников в мире 11,5 млн, или 17,2\%, составляют международные мигранты. Около 73,4 \% (или около 8,5 млн) всех домашних работников-мигрантов - женщины. Больше всего женщин-мигрантов трудится на домашних работах в странах Юго-Восточной Азии и Тихоокеанского региона $-24,0 \%$ от общего числа в мире, далее следуют страны Северной, Южной и Западной Европы, где в домохозяйствах работает $22,1 \%$ женщин-мигрантов, затем - арабские государства, где на домашних работах трудится 19,0\% женщин-мигрантов.

Учитывая старение населения и другие демографические и социально-экономические изменения, работники-мигранты, скорее всего, продолжат в больших количествах иммигрировать в другие страны, удовлетворяя потребность в работниках сферы ухода и домашних услуг, говорится в докладе МОТ. «Во многих смыслах вопросы миграции занимают центральное место в Программе устойчивого развития до 2030 года. Мигрантам нужна работа, и в то же время совершенно ясно, что в предстоящие годы многим странам назначения будут нужны новые работники. Миру понадобится все больше более точных данных и показателей для отслеживания потоков мигрантов, и данный доклад устанавливает новую планку в предоставлении точной глобальной статистики, необходимой для разработки политических мер», - таков неутешительный итог, подведенный директором Департамента статистики МОТ Рафаэль Диез де Медины (Rafael Diez de Medina) (Международное бюро труда, 2015).

Дискуссия о роли мигращии в формировании рынка труда

Мировой рынок труда определяется как форма существования трудовой миграции. Вместе с тем, единый подход в вопросе определения термина «международная миграция» отсутствует. Существуют разные толкования понятия термина «миграция». В их основе заложен определенного рода акцент на важнейшие аспекты данного института. Среди общераспространенных понятий под миграцией населения и трудовых ресурсов понимаются процессы, возникающие на основе территориальной мобильности. Соот- ветственно, «миграция (от лат. migratio - переселение) населения» обозначает перемещение, переселение, к примеру, населения внутри государства либо из одного государства в другое». С социологической точки зрения, процесс миграции населения «охватывает смену места жительства, т.е. перемещения из одних населенных пунктов в другие» (Заславская, 2009:11).

Вопрос о двух путях развитии миграционных процессов был поставлен на научную дискуссию давно, еще Карлом Марксом в годы изучения им развития капитализма. Один из них определен Марксом как «экстенсивный путь», характерный для миграций, начиная с Древнего мира до эпохи первоначального накопления капитала. Главной причиной миграционных перемещений называлась низкая производительность труда в области материального производства, вынуждавшая рабочих мигрировать в другие государства и искать средства к существованию. Это так называемая «вынужденная» миграция, понятие, введенное К. Марксом. Угрозой же для существования цивилизации он считал превышение пределов численности населения (Маркс, 1957: 565-568).

Интенсивный путь развития миграции назван Марксом вторым вариантом развития цивилизации и рынка труда, который напрямую связан с техническим прогрессом. Вывод Маркса о том, что рост производительных сил требует уменьшения численности населения, а «голод и эмиграция» способствуют устранению его избыточной части, звучит угрожающе. Однако ряд современных исследователей склоняется к подобным выводам.

Анализируя экономические факторы и особенности перемещения рабочей силы, ряд исследователей предлагают выделять отдельно взятые виды миграции и трактовать институт миграции в более узком понимании, а именно, как специфическое социально-экономическое явление, содержащее проблемные и противоречивые последствия. С точки зрения правовых примеров Евразийского пространства, обращается внимание на трудовое регулирование отношений и миграции (Идрышева, 2015).

Выделяется несколько подходов к определению понятия «миграция населения».

Так как внутригосударственные перемещения (внутренняя миграчия) лишь косвенно затрагивают проблему международного рынка труда, поэтому остановимся на внешних аспекmax миграчии, направленной за пределы государства. Под международной миграцией на- 
селения понимается внутриконтинентальная или межконтинентальная миграция, когда происходит территориальное (или пространственное) пересечение людей через государственные границы и имеется соответствующий контроль за фактом передвижения через границу (в стране выезда, и особенно - в стране въезда). Такие передвижения, наряду с изменением постоянного места жительства и гражданства, семейными, национальными, политическими причинами, обусловлены также долгосрочным пребыванием в стране въезда (более года) в связи с необходимостью циркулярных поездок на работу, трудоустройством и т.д. (Ионцев, 2009:326)

Более того, на международном рынке труда на постоянной основе выступают покупатели и продавцы заграничной рабочей силы, участвующие в процессе отбора необходимой рабочей силы в рамках межгосударственного регулирования спроса-предложения рабочей силы. Значительный экспорт частного производственного капитала позволяет во многих странах мира создавать иностранные предприятия при обязательном условии использования местной рабочей силы. В результате интернационализации экономики повысилась международная мобильность капитала. В плане социальных отношений это привело к тому, что капитал теперь предъявляет достаточно большой спрос на рабочую силу не только своего национального государства, но также на иностранную рабочую силу, нередко имеющую преимущества в том плане, что она молодая, более дешевая, более дисциплинированная, более доступная (Потуданская, 2014: 246).

Нельзя не согласиться с утверждением о том, что международный рынок рабочей силы функционирует как наднациональное образование. Он объединяет национальные и региональные рынки рабочей силы, охватывает разнонаправленные потоки трудовых ресурсов, пересекающие национальные границы.

Международная миграция и международный мигрант, причины миграчзии

Сложный процесс миграции населения вызвал появление многих теорий, объясняющих причины и механизмы миграции. «Международная миграция» уже по самому определению включает все виды перемещений через государственные границы, а «международным мигрантом» является «лицо, которое совершает межгосударственное территориальное передвижение (международную миграцию), преследуя цель сменить место жительства и работы, навсегда или на определённый срок (от 1 дня до нескольких лет)» (Ивахнюк, 2005:14).

В общем и целом, понятие «международный мигрант» определяется как «лицо рабочей силы», участвующее в процессе по перемещению трудовых ресурсов из одной страны в другую в целях трудоустройства на более выгодных условиях, чем в стране нахождения», то есть там, где действуют законы спроса и предложения на рынке труда (Похлебаева, 2005: 4-10). Имеются однозначные утверждения в пользу рационального понимания миграции рабочей силы (Колосницына, 2005). Авторы, дающие существенные дополнения в определение «международной миграции населения», подтверждают критерий рациональности феномена трудовой миграции. Итак, миграция определяется как территориальные (пространственные) передвижения людей через государственные границы, которые связаны с переменой места жительства и гражданства, обусловленные разными факторами (это могут быть семейные, национальные, политические и ряд других факторов). Передвижения связаны с долгосрочным пребыванием в стране въезда (более 1 года) либо имеют сезонный или маятниковый характер, либо связаны с постоянными поездками на работу, отдых и т.д. (Ионцев, 2009: 326).

Наряду с имеющимся массивом научных исследований по теме миграции, сегодня отсутствует единое общепринятое определение «международной миграции». В плане дискуссии по теоретическим аспектам трудовой миграции интересна работа Нестерова А.А. (Нестерова, 2017). К разряду регулярной миграции причисляются ежедневные маятниковые и приграничные миграции. Маятниковыми мигрантами называют людей, у которых место жительства и место стабильной работы расположены в различных местах. Это обстоятельство вынуждает людей поутру приезжать на работу и каждый вечер возвращаться к месту постоянного жительства (например, жители близлежащих районов области работают на предприятиях областного центра).

Приграничные мигранты (их еще называют «фронтальерами») очень похожи на маятниковых мигрантов, однако имеют существенное отличие - им приходиться пересекать государственную границу (живут в одной стране, а работают в другой).

Миграционный поток - это вся сумма переселений, которые произошли в определённое время в рамках той или иной территориальной 
системы. Структуры миграционного потока имеют следующие обязательные зависимости - пол и возраст мигрантов, их национальные особенности, семейное положение и т.д. (Потуданская, 2014: 32-33).

Таким образом, международный мигрант это физическое лицо, которое намеренно осуществляет межгосударственное территориальное передвижение, преследуя основную цель - трудоустройство, но и возможность сменить место жительства.

Эмпирические исследования миграции показывают определенную аналогию во многих странах - закономерности, подвигающие население к миграции. Серьезными аргументами в пользу трудовой миграции являются возраст мигранта. В вопросах, касающихся условий занятости, доминирующим фактором выступает плата за труд. Для страны реципиента или для приглашающего лица категория «возраст» влияет на принятие решения. Оно принимается в зависимости от того, насколько длительно по времени работодатель будет получать выгоду от инвестиций в человеческий капитал, который реализуется в форме миграции (Колосницына, 2005).

Выявлена возрастная категория потенциальных мигрантов. «Наибольшая склонность к миграции наблюдается у молодых людей в возрастном диапазоне от 20 до 24 лет, практически $13 \%$ представителей молодежи в данной возрастной группе ежегодно принимают решение о внутренней либо международной миграции» (Колосницына, 2005). Для молодежи типична нерегулярная погода (к примеру, это может быть сбор урожая).

Челночные миграции были распространены в 90-е годы на постсоветском пространстве, характеризующиеся периодическими выездами, которые могут быть разными по периоду нахождения за границей (к примеру, выезд коммерсантов («челноков») за товаром) с обязательным возвращением к месту постоянного проживания.

Вахтовые миграции определяются наличием особенностей условий работы и нахождения работников на территориях с неблагоприятными климатическими условиями (в качестве примера можно привести выезд сотрудников нефтяной промышленности к месту непосредственной добычи нефти на Севере) (Нестерова, 2017).

Вопрос о том, почему в миграционный процесс втягиваются все большие массы людей и все большее число стран, был поставлен еще классиками политической экономии, продолжает оставаться предметом исследований. Так, ин- ституциональная теория сосредотачивает внимание на формировании миграционной политики и миграционных потоков, а также на роли международных организаций.

По теории миграции американского экономиста Майкла Тодаро, предложившего свою «мигращионную модель», миграция из села в город рассматривается как рациональный процесс, несмотря на высокий уровень безработицы в городе. Аналогичным образом данную модель можно сфокусировать на исследовании принципа рациональности применительно к миграции трудовых ресурсов из более бедных стран в более богатые. Обращает на себя парадокс Тодаро, открытый им в ходе исследования трудовой миграции, согласно которому любые мероприятия, направленные на улучшение городской экономики, приводят к росту городской безработицы, так как эти улучшения стимулируют ещё большую миграцию из сельских территорий. Работники сравнивают свои ожидаемые доходы в городе и начинают переселение из села в случае, если эти ожидаемые доходы превышают их средний уровень доходов в селе (Todaro, 1969: 138-148).

Экономическое неравенство и неравенство между странами, как утверждает неоклассическая теория, являются основными причинами, вызывающими международную миграцию. Одно из объяснений лежит в исторической и традиционной взаимосвязи между метрополиями и бывшими колониями (общность языка, культуры, административного устройства и т.д.), и особенности миграции.

Наличие разницы в уровнях оплаты труда способствует движению рабочей силы из государств с низкой заработной платой в государства с высокой заработной платой. Именно это обстоятельство способствует выравниванию уровней заработной платы на мировом рынке труда.

В исследовании Р. Билсборроу и др. присутствует точка зрения, не вступающая на первый взгляд в особые противоречия с предыдущими взглядами. Речь идет о попытке расширить определение миграции рабочей силы причинноследственными связями. Так, причиной территориального перемещения трудовых ресурсов выступает сильная мотивация индивида трудоустроиться на определённый срок и вместе с этим сменить место/страну проживании (Билсборроу, 1999: 400).

Принимая во внимание факт того, что международная трудовая миграция является важнейшей составляющей международной миграции 
населения, её характерными чертами являются добровольность, временность/возвратность и экономическая мотивация. Выделяется ряд основных причин, непосредственно связанных с переселением:

- причины социально-экономического порядка (уезжают в поисках более высокооплачиваемой работы или же лучших условий жизни и труда);

- политические причины (бегство от вероятных притеснений или репатриация из государства постоянного проживания);

- по причине военных действий (речь об эвакуации, реэвакуации, депортации) (Доугерти, 2010: 402)

Наибольшее распространение в вопросах изучения трудовой международной миграции получила теория общемировой миграционной системы, которая апеллирует к принципам глобализации, для которой характерны общие тенденции развития мировых трудовых миграций и инкорпорация отдельно взятых стран единую мировую системы.

Таким образом, причина и направления миграционных потоков обусловлены степенью интеграции государства в мировое хозяйство, а также его участием в международных и региональных группировках, блоках, соглашениях, ассоциациях. Данная теория указывает, что развитие агентств и разного рода институтов, которые содействуют в получении требуемых информации и языковой поддержке, способствует миграционным потокам (Бондарь, 2006:168). Кроме всего перечисленного, на динамику процесса миграции влияет развитие мировой транспортной системы и средств коммуникации (Лоури) (Lawry, 1966: 67-71).

Миграчия как способ инвестищуий в «человеческий капитал»

Связь внешней трудовой миграции и экономического развития в стране выезда доказана на макроуровне. Согласно теории человеческого капитала, миграция рассматривается в качестве способа инвестиций в «человеческий капитал», требуемый для создания рынка труда. В свою очередь, рынок труда формируется в условиях действия трех основных факторов миграции: условия занятости в своей стране и в государстве назначения; возраст; издержки переезда.

Объяснение понятия инвестиции в «человеческий капитал» в виде соответствующих схем предложил Питер Стокер (Питер Стокер, 1996: 26-27), обозначив их как индивидуальный, структурный и системный подходы. С точки зрения концепции человеческого капитала индивидуальный подход заключается в рассмотрении человека продуктом инвестиций таких сфер, как образование, здоровье, квалификация. Опыт инвестирования в человеческий капитал, практикуемый в зарубежных странах, способствует качественному развитию и изменению рабочей силы. По этой причине миграцию считают дополнительным вложением в человеческий капитал.

Благодаря структурному подходу, анализируются разные условия проживания, деятельности индивида, прежде всего социальные, политические и экономические условия. Значительная роль отводится информационным структурам (речь о средствах массовой информации, в первую очередь телевидении, информации от соседей, родственников, которые преуспели в результате миграции). СМИ помогают человеку узнать о дополнительных возможностях, которые открываются перед ним благодаря переезду в другое государство.

Согласно «теории социальной сети» наличие связей между мигрантами и их друзьями и родственниками, которые остались на родине, способно выступить в роли инициатора новых миграционных перемещений. Такие социальные сети приводят к снижению рисков и затрат вновь прибывших, а также способствуют распространению подобного рода сетей в местах происхождения и прибытия мигрантов и к росту потенциала внешней трудовой миграции.

В реальной жизни разные подходы при объяснении причин, которые вызывают миграцию, совмещаются. Восполнить ограниченность неоклассического подхода пытается концепция новой экономики миграции, стремящаяся осуществить синтез микро- и макроподходов. На принятие решения о миграции оказывают влияние все члены домохозяйства. Цель миграции максимизация ожидаемого дохода и сведение к минимуму риска, который связан с потенциальной возможностью оказаться в рядах безработных в своей стране по причине слабого развития рынка труда и т.д. В данном случае минимизация риска может являться доминирующим фактором в процессе принятия решения о миграции (Massey, 1993:431-466.).

В соответствии с теорией «процветания», или «технологического разрыва», наличие огромного количества мигрантов может являться одним из условий процветания принимающего общества, а также лежать в основе экономического и демографического процветания. 


\section{Заключение}

Теории международного рынка труда, движения и регулирования рабочей силы и концептуальные подходы к мировой миграционной системе, сформулированные разными авторам разных научных направлений и школ в разные времена, являются темой бурных дискуссий и сегодня, применительно к вызовам глобализации.

В современных условиях при решении проблем рынка труда и занятости в той или иной стране используются разные теории, а нередко отдельные положения нескольких теорий. Рассмотренные выше теоретические позволяют анализировать международную миграцию не просто в качестве результата индивидуальных решений, находящихся в зависимости от тех или других факторов, а в контексте мировых потоков капиталов и товаров и взаимодействия целого ряда глобальных факторов - политических, экономических и культурных. Благодаря этому появляется сложная система, которая состоит из разных элементов, оказывающих влияние на процесс миграции.

В ходе анализа подтвердилось утверждение о том, что международные трудовые миграции в развитые государства являются результатом просчётов на других, менее привлекательных и эффективных рынках, которым свойственны недостаточное развитие или несовершенство рынков капитала, страхования и инвестиций. Наличие разницы в оплате труда в подобных условиях может выступать в качестве стимула в выборе рынка труда, однако ее нельзя считать единственным фактором, который способствует международным перемещениям рабочей силы.

Миграция населения рассматривается через призму территориального перемещения людей, целью которого является поиск нового трудоустройства и более благоприятные условия труда. При этом следует выделять внутреннюю и внешнюю миграцию, учитывая географию и направления перемещений. Применение микроэкономического подхода к трудовой миграции можно реализовать и в рамках модели миграции (М. Тодаро).

Соответственно, «международная трудовая миграция - категория, которая непосредственно взаимосвязана с пересечением границы страны с целью предложения рабочей силы в государстве въезда на определённый срок». Итак, факторы, которые определяют международную миграцию, - это спрос и предложение рабочей силы в различных регионах мира, дифференциация в размерах заработной платы, а также политические, демографические и ряд других процессов. Под «международной миграционной системой» понимается определенная совокупность основных принимающих регионов в странах прибытия мигрантов и совокупность основных регионов, отдающих мигрантов в странах их происхождения. Следует отметить, что данная теория учитывает процесс принятия решения о миграции на уровне индивида и хозяйства. В целом, отечественная наука призвана учитывать мировой опыт и специфику казахстанской действительности для разработки наиболее приемлемых концепций рынка труда, способного интегрироваться в мировую систему рынка труда.

\section{Литература}

1 Казахстан вошел в тридцатку мировых лидеров по фактору эффективности рынка труда // Zakon.kz [https://www. zakon.kz/4863654-kazahstan-voshel-v-tridtsatku-mirovyh.html], 13 июня 2017

2 Смит А. Исследование о природе и причинах богатства народов: В 2 т. - М.: Наука, 1993. - Т. 1. - 570 с.; также ряд работ выдающихся мыслителей прошлого, см.: Антология экономической классики. У. Петти, А. Смит, Д. Рикардо. - М., 1993. $-486 \mathrm{c}$.

3 Милль Дж. Ст. Принципы политической экономии с некоторыми приложениями к социальной философии. - М.: Эксмо, 2007. - 1040 c. (John Stuart Mill Principles of political Economy, with some of their applications to Social Philosophy)

4 Маркс К. Капитал. Критика политической экономии: В 3 т. - М.: Политиздат, 1989. - 508 с.

5 Маршалл А. Основы экономической науки. - М.: Эксмо, 2007. - 832 с.

6 Фридмен М., Хайек Ф. О свободе. - М.: Социум; Три квадрата, 2003. - 149 с.

7 Кейнс Дж. М. Общая теория занятости, процента и денег. Избр. произ. - М.: Экономика, 1993. - 287 с.

8 Мальтус Т. Опыт о законе народонаселения // Антология экологической классики. - M., 1993. - C. 3-134 (The Works of Thomas Robert Malthus / ed. by E. A. Wrigley, D.Souden. - L, 1986, v. 1-8)

9 Осборн Д., Пластрик П. Управление без бюрократов: пять стратегий обновления государства / Общ. ред. Л.И. Лопатникова. - М.: Прогресс, 2001. - 533 с.

10 Международная организация труда. Многосторонние основы МОТ по вопросам миграции рабочей силы. Не обязательные в правовом отношении нормы и руководящие принципы подхода к миграции рабочей силы, основанного на 
соблюдении прав человека. МОТ, Женева, 2007 // МОТ. Режим доступа: [http://www.ilo.org/wcmsp5/groups/public/ed_norm/ normes/documents/normativeinstrument/wcms_c097_ru.htm]

11 Конвенция № 143 «О злоупотреблениях в области миграции и об обеспечении трудящимся-мигрантам равенства возможностей и обращения» // Zakon,kz. Режим доступа: [https://online.zakon.kz/Document/?doc_id=1018307]

12 Международная конвенция о защите прав всех трудящихся-мигрантов и членов их семей. Резолюция 45/158 Генеральной Ассамблеи от 18 декабря 1990 года // ООН. Конвенции и соглашения. Режим доступа: [http://www.un.org/ru/ documents/decl_conv/conventions/migrant.shtml]

13 Губайдуллина М.Ш., Ярмухамедов Д.М. Международно-правовые аспекты регулирования трудовой миграции в конвенциях Международной организации труда (МОТ) // Вестник КазНУ. Серия МО и МП.- 2004.- № 4 (16). - С.104-111

14 Доклад Глобальные оценки МОТ по работникам-мигрантам 2015 г. (ILO Global Estimate on Migrant Workers)// Международное бюро труда (МБТ), Женева/ Режим доступа: [http://www.ilo.org/global/topics/labour-migration/news-statements/WCMS436140/lang--ru/index.htm]

15 Заславская Т.И. Миграция сельского населения. - М.: Мысль, 2009.

16 Маркс, К. Вынужденная эмиграция / К. Маркс, Ф Энгельс. Соч. 2-е изд. - М., 1957.

17 Правовое регулирование экономических отношений в ЕврАзЭС/ЕАЭС: монография / отв. ред. С.К. Идрышева. Астана, 2015

18 Ионцев В.А. Международная миграция населения: теория и история изучения. - М.: Диалог МГУ, 2009. - 326.

19 Потуданская В.Ф., Бояркин Г.Н., Юсова Ю.С. Трудовая миграция как фактор трансформации регионального рынка труда. - Омск: изд-во ОмГТУ, 2014. - 246 с

20 Ивахнюк И. В. Международная трудовая миграция. - М., 2005

21 Похлебаева О. Понятие миграции и ее классификация // Мировая экономика и международные отношения. -2005. - № 3. - С. 4-10

22 Колосницына М.Г., Суворова И.К. Международная трудовая миграция: теоретические основы и политика регулирования // Экономический журнал ВШЭ. - 2005. - № 4. Режим доступа: [http://library.hse.ru/e-resources/HSE_economic journal/-articles/09_04_05.pdf/]. Дата доступа: 07. 01.2017

23 Нестерова А.А. Ретроспективный взгляд на теории, объясняющие трудовую миграцию. Режим доступа: [http://elib. bsu.by/bitstream/123456789/5396/1/nesterova_2011_8_IER_issues_r.pdf], Режим доступа: 02.02.2017

24 Todaro M.P. A Model of Labor Migration and Urban Unemployment in Less Developed Countries // The American Economic Review. - 1969. - Vol. 59, № 1. - P. 138-148

25 Билсборроу P.Е., Хьюго Г., Оберай А., Злотник Х. Статистика международной миграции. Рекомендации по совершенствованию систем сбора данных. - М.: Academia, 1999. - 400 с.

26 Доугерти К. Введение в эконометрику: пер. с анг. - М.: ИНФРА-М., 2010. - 402 с.

27 Бондарь, А. В. Человеческий капитал в контексте макроэкономической стабилизации и конкурентоспособности национальной (малой открытой) экономики /А. В. Бондарь, М. А. Бондарь, И. В. Корневец, Л. Н. Маркусенко. - Минск, 2006

28 Lawry I. Migration and Metropolitan Growth: Two Analitical Models. San-Francisco. - 1966. - Pp. 67-71.

29 Стокер П. Работа иностранцев: обзор международной миграции рабочей силы. - М., 1996

30 Massey D. S., Arango J., Hugo G., Kouaouci A., Pellegrino A., and Taylor J. E. (1993). Theories of International Migration: Review and Appraisal. Population and Development Review, 19(3): 431-466.

\section{References}

1 Kazahstan voshel v tridcatku mirovyh liderov po faktoru jeffektivnosti rynka truda // Zakon.kz [https://www.zakon. kz/4863654-kazahstan-voshel-v-tridtsatku-mirovyh.html], 13 ijunja 2017

2 Smit A. Issledovanie o prirode i prichinah bogatstva narodov: V 2 t. - M.: Nauka, 1993. - T. 1. - 570 s.; takzhe rjad rabot vydajushhihsja myslitelej proshlogo, sm.: Antologija jekonomicheskoj klassiki. U. Petti, A. Smit, D. Rikardo. - M., 1993. - 486 s.

3 Mill' Dzh. St. Principy politicheskoj jekonomii s nekotorymi prilozhenijami k social'noj filosofii. - M.: Jeksmo, 2007. 1040 s. (John Stuart Mill Principles of political Economy, with some of their applications to Social Philosophy)

4 Marks K. Kapital. Kritika politicheskoj jekonomii: V 3 t. - M.: Politizdat, 1989. - 508 s.

5 Marshall A. Osnovy jekonomicheskoj nauki. - M.: Jeksmo, 2007. - $832 \mathrm{~s}$.

6 Fridmen M., Hajek F. O svobode. - M.: Socium; Tri kvadrata, 2003. - 149 s.

7 Kejns Dzh. M. Obshhaja teorija zanjatosti, procenta i deneg. Izbr. proiz. - M.: Jekonomika, 1993. - $287 \mathrm{~s}$.

8 Mal'tus T. Opyt o zakone narodonaselenija // Antologija jekologicheskoj klassiki. - M., 1993. - S. 3-134 (The Works of Thomas Robert Malthus / ed. by E. A. Wrigley, D.Souden. - L, 1986, v. 1-8)

9 Osborn D., Plastrik P. Upravlenie bez bjurokratov: pjat‘ strategij obnovlenija gosudarstva / Obshh. red. L.I. Lopatnikova. M.: Progress, 2001. -533 s.

10 Mezhdunarodnaja organizacija truda. Mnogostoronnie osnovy MOT po voprosam migracii rabochej sily. Ne objazatel'nye $\mathrm{v}$ pravovom otnoshenii normy i rukovodjashhie principy podhoda $\mathrm{k}$ migracii rabochej sily, osnovannogo na sobljudenii prav cheloveka. MOT, Zheneva, 2007 // MOT. Rezhim dostupa: [http://www.ilo.org/wcmsp5/groups/public/ed_norm/normes/documents/ normativeinstrument/wcms_c097_ru.htm]

11 Konvencija № 143 «O zloupotreblenijah v oblasti migracii i ob obespechenii trudjashhimsja-migrantam ravenstva vozmozhnostej i obrashhenija» // Zakon,kz. Rezhim dostupa: [https://online.zakon.kz/Document/?doc_id=1018307] 
12 Mezhdunarodnaja konvencija o zashhite prav vseh trudjashhihsja-migrantov i chlenov ih semej. Rezoljucija 45/158 General'noj Assamblei ot 18 dekabrja 1990 goda // OON. Konvencii i soglashenija. Rezhim dostupa: [http://www.un.org/ru/documents/decl_conv/conventions/migrant.shtml]

13 Gubajdullina M.Sh., Jarmuhamedov D.M. Mezhdunarodno-pravovye aspekty regulirovanija trudovoj migracii v konvencijah Mezhdunarodnoj organizacii truda (MOT) // Vestnik KazNU. Serija MO i MP.- 2004.- № 4 (16). - S.104-111

14 Doklad Global'nye ocenki MOT po rabotnikam-migrantam 2015 g. (ILO Global Estimate on Migrant Workers)//Mezhdunarodnoe bjuro truda (MBT), Zheneva/ Rezhim dostupa: [http://www.ilo.org/global/topics/labour-migration/news-statements/ WCMS436140/lang--ru/index.htm]

15 Zaslavskaja T.I. Migracija sel'skogo naselenija. - M.: Mysl`, 2009.

16 Marks, K. Vynuzhdennaja jemigracija / K. Marks, F Jengel‘s. Soch. 2-e izd. - M., 1957.

17 Pravovoe regulirovanie jekonomicheskih otnoshenij v EvrAzJeS/EAJeS: monografija / otv. red. S.K. Idrysheva. - Astana, 2015

18 Ioncev V.A. Mezhdunarodnaja migracija naselenija: teorija i istorija izuchenija. - M.: Dialog MGU, 2009. - 326.

19 Potudanskaja V.F., Bojarkin G.N., Jusova Ju.S. Trudovaja migracija kak faktor transformacii regional'nogo rynka truda. Omsk: izd-vo OmGTU, 2014. - 246 s

20 Ivahnjuk I. V. Mezhdunarodnaja trudovaja migracija. - M., 2005

21 Pohlebaeva O. Ponjatie migracii i ee klassifikacija // Mirovaja jekonomika i mezhdunarodnye otnoshenija. - 2005. - № 3. - S. 4-10

22 Kolosnicyna M.G., Suvorova I.K. Mezhdunarodnaja trudovaja migracija: teoreticheskie osnovy i politika regulirovanija // Jekonomicheskij zhurnal VShJe. - 2005. - № 4. Rezhim dostupa: [http://library.hse.ru/e-resources/HSE_economic_journal/-articles/09_04_05.pdf/]. Data dostupa: 07. 01.2017

$23^{-}$Nesterova A.A. Retrospektivnyj vzgljad na teorii, ob\#jasnjajushhie trudovuju migraciju. Rezhim dostupa: [http://elib.bsu. by/bitstream/123456789/5396/1/nesterova_2011_8_IER_issues_r.pdf], Rezhim dostupa: 02.02.2017

24 Todaro M.P. A Model of Labor Migration and Urban Unemployment in Less Developed Countries // The American Economic Review. - 1969. - Vol. 59, № 1. - P. 138-148

25 Bilsborrou R.E., H‘jugo G., Oberaj A., Zlotnik H. Statistika mezhdunarodnoj migracii. Rekomendacii po sovershenstvovaniju sistem sbora dannyh. - M.: Academia, 1999. - $400 \mathrm{~s}$.

26 Dougerti K. Vvedenie v jekonometriku: per. s ang. - M.: INFRA-M., 2010. - $402 \mathrm{~s}$.

27 Bondar', A. V. Chelovecheskij kapital v kontekste makrojekonomicheskoj stabilizacii i konkurentosposobnosti nacional'noj (maloj otkrytoj) jekonomiki /A. V. Bondar', M. A. Bondar', I. V. Kornevec, L. N. Markusenko. - Minsk, 2006

28 Lawry I. Migration and Metropolitan Growth: Two Analitical Models. San-Francisco. - 1966. - Pr. 67-71.

29 Stoker P. Rabota inostrancev: obzor mezhdunarodnoj migracii rabochej sily. - M., 1996

30. Massey D. S., Arango J., Hugo G., Kouaouci A., Pellegrino A., and Taylor J. E. (1993). Theories of International Migration: Review and Appraisal. Population and Development Review, 19(3): 431-466. 
